\title{
Political Dynasty and Single Candidate in Indonesian Local Elections: Where Are The Parties?
}

Zaldi Rusnaedy ${ }^{1}$, Fatma ${ }^{2}$, Almuhajir Haris ${ }^{3}$

Universitas Pancasakti Makassar, Jl. Andi Mangerangi No. 73 Makassar

Corresponding Author: zaldi.rusnaedy.s@unpacti.ac.id

\section{Keyword:}

Political Dynasty;

Single Candidate;

Political Recruitment;

Candidate Election
Kata Kunci:

Dinasti Politik:

Calon Tunggal;

Rekrutmen Politik;

Seleksi Kandidat

\begin{abstract}
The pragmatism of political parties is one of the causes for the proliferation of political dynasties and the massive number of single candidates in several electoral politics periods at the local level. The implementation of the 2020 local election simultaneously gave birth to many candidates who have a kinship with political officials both at the central and regional levels, both currently or who have served. Apart from the practice of dynastic politics, a single candidate's presence also adds to the problems in the democratic process at the local level. A single candidate is present as a consequence of implementing the local election system simultaneously, which opens wide the opportunity for the local election to be held even though only one pair of regional head candidates are joined, as a consequence, the empty column is presented as the opponent of the match. This article collects data through a literature study. To answer these two phenomena, the author examines them during the local election implementation. This study indicates that these two phenomena co-opt local democracy and clog the circulation of the leadership elite. Both political dynasty candidates and single candidates have enormous potential to win elections. Both phenomena are caused by poor internal recruitment and candidate selection processes.
\end{abstract}

\begin{abstract}
Abstrak: Pragmatisme partai politik menjadi salah satu penyebab menjamurnya dinasti politik dan masifnya jumlah calon tunggal dalam beberapa periode politik elektoral di tingkat lokal. Penyelenggaraan Pilkada serentak 2020 melahirkan banyak calon yang memiliki kekerabatan dengan pejabat politik baik di tingkat pusat maupun daerah, baik yang saat ini maupun yang pernah menjabat. Selain praktik politik dinasti, kehadiran calon tunggal juga menambah persoalan dalam proses demokrasi di tingkat lokal. Hadirnya calon tunggal sebagai konsekuensi dari pelaksanaan sistem pemilihan kepala daerah secara serentak, yang membuka kesempatan seluas-luasnya bagi terselenggaranya pemilihan kepala daerah meskipun hanya diikuti oleh satu pasangan calon kepala daerah, akibatnya kolom kosong tersebut dihadirkan sebagai lawan pertandingan. Artikel ini mengumpulkan data melalui studi literatur. Untuk menjawab dua fenomena tersebut, penulis mengkajinya pada saat pelaksanaan pilkada. Studi ini menunjukkan bahwa dua fenomena ini mengkooptasi demokrasi lokal dan menyumbat sirkulasi elit kepemimpinan. Baik calon dinasti politik maupun calon tunggal memiliki potensi yang sangat besar untuk memenangkan pemilu. Kedua fenomena tersebut disebabkan oleh proses rekrutmen dan seleksi kandidat internal yang buruk
\end{abstract}

Informasi Artikel: Disubmit: 09-10-2021, Revisi: 29-10-2021, Diterima: 02-11-2021 


\section{INTRODUCTION}

The study of local politics has always attracted many circles, especially after 1998. Local election and decentralization became mass production of various local political phenomena. One of the phenomena that have attracted attention is political dynasties. Political scientists use various terms to explain the phenomenon of more than one family member in political office, including political dynasties, dynastic politics, kinship politics, political clans, and political families.

The definition of different terms is inseparable from the carefulness of scientists to provide limitations about this phenomenon. There is debate among scientists to categorize whether this includes a manifestation of political dynasties or not? Are all family members who take part in political office immediately generalized as a manifestation of a political dynasty or not? These debates are described by (Purwaningsih \& Subekti, 2017) by dividing 3 (three) dimensions: The time dimension (the previous political family had at least two periods of power); The number dimension ( 2 or more people); The position dimension (the same or different political positions).

The description above provides some limitations regarding the proper use of the term political dynasty. However, it has not been able to answer whether all family members, including those with political achievements, can be categorized as political dynasties? This generalization discredited family members who were related by blood to the previous ruler. However, on the other hand, almost every region throughout Indonesia, where many political positions are occupied by those who are related by blood. So that the circulation of power elites in the regions become clogged.

The absence of strict regulations to regulate nominations in electoral politics at both the executive and legislative levels is the source of the spread of political dynasties. Although the government through Law Number 8 of 2015 concerning the Election of Governors, Regents and Mayors, especially Article 7 letter $r$, which prohibits regional heads (incumbents) from running for regional heads. Candidates for governor, regent and mayor may not have marital ties, lineages upward, downward, and sideways unless there is at least one term of office (Purwaningsih \& Subekti, 2017). However, on July 8, 2015, the Constitutional Court revoked the ban because it was considered contrary to the 1945 Constitution Article 28J paragraph 2 concerning every citizen's political rights to vote and be elected in general elections. This problem becomes a dilemma increasingly; on the other hand, the network of family power that controls an area is getting stronger, but on the other hand, if this is prohibited, it will circumcise citizens' political rights that the constitution has regulated.

This political dilemma in a theoretical review is described by (Purwaningsih \& Subekti, 2017) by classifying political officials as a political manifestation or not, through the following chart:

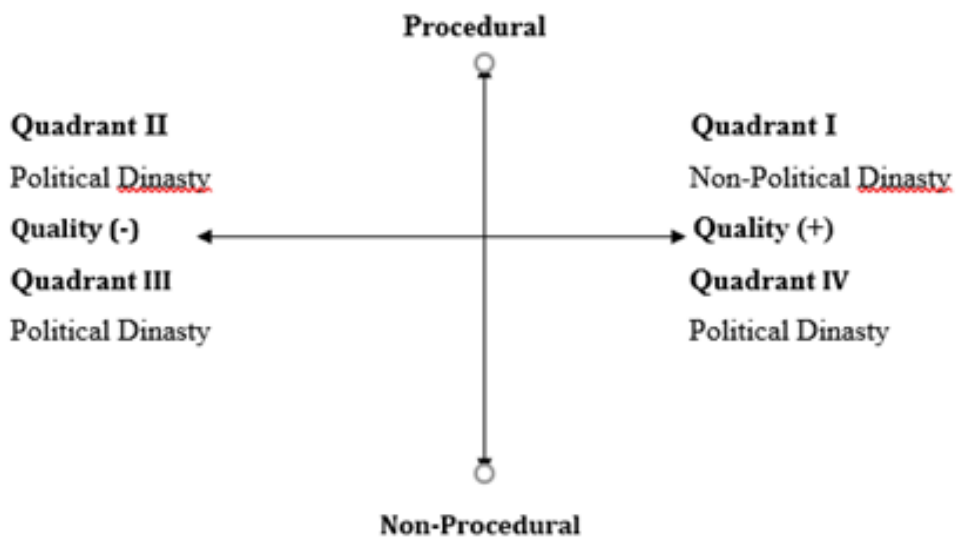

Chart 1. Classification of Dynastic Political Manifestations Source: (Purwaningsih \& Subekti, 2017) 
The chart above divided into 4 (four) quadrants can be read: quadrant I is not a political dynasty because it goes through a political recruitment process following procedures and has quality based on the qualifications needed in the political recruitment process. Meanwhile, the other 3 (three) quadrants are political dynasties' manifestations because they do not fulfil one or even the two elements. The analysis put forward by (Purwaningsih \& Subekti, 2017) uses a political approach by concluding that the political recruitment process is the entry point for massive political dynasty practices. This means that political parties, as the production containers for political candidates, perpetuate political dynasties, both during political recruitment and in the process of candidate selection.

The description above is only one of the factors behind the many factors that have been investigated by previous researchers regarding the massive and perpetual practice of political dynasties. Smith (2012) and Querubin (2013) highlight the electoral system that incumbents open up to include other family members in political office. Another factor behind the formation of political dynasties is the poor recruitment and candidate selection process of political parties as studied by Fiva \& Smith (2013), Geys (2017), and Purwaningsih \& Subekti (2017). The results of the research shown by Feinstein (2010) and Buehler, 2007 show that the big name of the family is the main trigger for other family members also to take part and enjoy the political legacy of the previous ruler.

The factors that shape and perpetuate political dynasties are more due to the ownership of capital, social, economic, political, cultural, and symbolic, so that non-dynastic candidates cannot compete. This reason was stated by Mendoza et al. (2012); Rusnaedy (2020); Rusnaedy \& Purwaningsih (2018). The ownership of economic capital, which is operationalized, can make it easier when a political campaign is held. The strength of social networks and big names of families built by the incumbent is used as a political commodity to get as many votes as possible. This capital inheritance is passed down and enjoyed by relatives who make it easier to enjoy political office through electoral political contestation (Smith, 2012).

In the Indonesian context, the formation of political dynasties was more due to decentralization and direct local election, which provided space for local elites in regions that previously only controlled the economic field to become local political elites. This research is strengthened by descriptions of local elites (Hamid, 2015). The author sees these researchers as referring to the research results (Sidel, 2005) about local bosses in the Philippines, Thailand and Indonesia. Hadiz (2004), although not directly addressing political dynasties, in his findings, it is revealed that decentralization is an anomaly of local democratic practices in Indonesia. This means that many problems are presented through the decentralized system and local election that are implemented in Indonesia, which in any case, are the most problematic. This includes the growing network of family political power in several regions in Indonesia. There are 108 of the 548 regions in Indonesia which are led by regional heads and deputy regional heads related to political dynasties.

In recent periods, apart from political dynasties, a single candidate's presence has also become a matter of electoral politics in the regions. Both have a thick tangent. The presence of a single candidate has continuously increased from the 3 (three) local election periods held. In 20153 regions had a single candidate from 269 regions that held local election. In 2017 there were nine single candidates from 101 regions who held local election contestation. In 201816 regional head candidates were single candidates. In 2020, a single candidate's presence had increased significantly compared to the previous local election; namely, there are 25 regions.

The phenomenon of a single candidate presenting the Empty Column as a match has damaged the substance of political contestation, which has eliminated healthy competition between candidates. The increase in a single candidate in each local election implementation is an anomaly because Indonesia adheres to a multi-party system. Supposedly, every party or coalition of political parties should bring their best cadres to advance in every election for political officials. So far, there are two types of single candidates: a single candidate for the incumbent and a single candidate for the family of the person in power.

The problem is that the single candidate who generally is the incumbent does not always have a good performance. This phenomenon raises the suspicion of an agreement between a political 
party and a single candidate. Anggraini argues that if the incumbent's performance is not good, the performance is not supportive, and the candidates who emerge are still single, there will be allegations of pragmatism and transactional politics (Jay, 2018). A single candidate is legal based on the regulation on regional head elections. However, this undermines democracy. Political competition for the best results has stalled. A single candidate who is elected later will be difficult to control because they support the majority of seat holders in the legislature.

\section{METHOD}

This article focuses on the analysis of single political dynasties and candidates in several local election implementations. The research method used in this paper is library research. The analysis is based on collecting secondary data based on literature collected from various supporting literature, scientific journals, books, research reports, and relevant research reports. Information sourced from the literature search results is researched and analyzed to obtain the latest information data from the results of data collisions from several previous secondary data sources. The researchers chose the literature review to complete the data information from previous research on political dynasties and single candidate.

\section{Single Candidate and Political Dynasty}

\section{RESULTS AND DISCUSSION}

The local election is not only the momentum for five years of electoral politics in the regions, more than that, but the local election is also the foundation of local democracy that supports national democracy. In O'Neill's opinion, "all politics is local", which means that national democracy will be healthy, stable and mature if, at the local level, its democratic values are first rooted. This means that democracy at the national level will be better if the instruments, order, and configuration of local political wisdom and politeness are established earlier. That is, direct local election as one of the leading indicators of local democracy is also the primary foundation for political democracy in Indonesia. It is the same as the opinion expressed by Robert Bates that national political architecture is shaped by the local political landscape.

However, what is happening now is that the local democratic order has not been implemented very well (Nurmandi et al., 2015). Several diseases that have undermined the implementation of the local election have become increasingly acute since the simultaneous local election system was implemented. The government's good intention to carry out the local election simultaneously to make the budget efficient for the election is not directly proportional to the improvement of the quality of democracy. On the contrary, the strengthening of political dynasties and the proliferation of single candidates were terrible symptoms of the democratic process at the local level. These two phenomena co-opt the process of implementing electoral politics in the regions. Although these two phenomena do not have a direct causal relationship, they have a thick tangent at some point.

The simultaneous local election $(2015,2017$ and 2018) totalled 202 total attempts to form a political dynasty. Candidates have kinship relations with political officials both at the central and regional levels and have held positions. Although in the end, political dynasties were unable to control absolutely by winning political contestations. The political dynasty candidates won $58 \%$ and lost $42 \%$ of the total attempt.

Table 1. Political Dynasties of Local Elections 2015-2018

\begin{tabular}{llccc}
\hline No & Status & Total Effort & Win & Lost \\
\hline 1 & District head & 146 & 82 & 64 \\
2 & Deputy Regional Head & 56 & 35 & 21 \\
& Total & 202 & 117 & 85 \\
\hline
\end{tabular}

Source: Perludem, 2020

In the 2020 local election contest, 52 regional head candidates were indicated to have a kinship with political officials. Of these, $71.5 \%$ of candidates will advance at the district level, with 27 candidates for regent and ten candidates for deputy regent. Meanwhile, $25 \%$ of 
candidates indicated that advanced political dynasties at the city level consisted of 10 candidates for mayor and three candidates for deputy mayor. Below are some candidates (not listed as all) who have a kinship with politicians at both the central and regional levels.

Table 2. Political Dynasties of Local Election 2020

\begin{tabular}{ccccc}
\hline No & $\begin{array}{c}\text { Candidate for } \\
\text { Regional Head }\end{array}$ & Area & $\begin{array}{c}\text { Kinship } \\
\text { Relationship }\end{array}$ & Bearer Parties \\
\hline
\end{tabular}
$1 \begin{aligned} & \text { Gibran Rakabuming } \\ & \text { Raka }\end{aligned}$

PDIP, Gerindra, Golkar,

NasDem, PAN, PSI, PKB and PPP

2 Bobby Afif Nasution

Mayor of
Medan

3 Siti Nur Azizah

4 Rahayu Saraswati Djojohadikusumo

5 Pilar Saga Ichsan

6

Hanindhito Himawan

Pramono

$7 \quad$ Irman Yasin Limpo

8 Titik Masudah

9 Ratu Munawaroh

10 Lisa

11 Ipuk Fiestiandani

12 Herny

13 Yunita Asmara

14 Eva Dwiana
Mayor of South Ma'ruf Amin's

Tangerang

Deputy Mayor

of South

Tangerang

Deputy Mayor

of South

Tangerang

Regent of Kediri

Mayor of

Makassar

Deputy Regent of Mojokerto

Deputy

Governor of

Jambi

Mayor of Binjai

\section{Regent of}

Banyuwangi

Deputy Regent

of Pasangkayu

Regent of

Batanghari

Mayor of

Bandar

Lampung
Joko Widodo's

Son-in-law

Son

Prabowo

Subianto's Niece

Ratu Atut

Chosiyah's

Nephew

Pramono

Anung's Son

Brother Syahrul Yasin Limpo

Sister Ida

Fauziah

Zumi Zola's

Mother

Muhammad

Idaham's Wife

Abdullah Azwar

Anas's Wife

Agus Ambo

Djiwa's Wife

Syahirsah's Wife

Herman

Hasanusi's Wife
PDIP, Gerindra, PAN, Golkar, NasDem, Hanura, PSI and PPP

PKS, Demokrat and PKB

Gerindra, PDIP, PSI, PAN

and Hanura

Golkar

PKB, Gerindra, PDIP, Golkar, NasDem, PKS, PPP, PAN and Demokrat

Golkar, PAN and PKS

PKB, PBB and PDIP

PDIP and Golkar

PDIP, NasDem, PAN and Hanura

PDIP, NasDem, Gerindra, PPP and Hanura

Golkar, PDIP, Gerindra, Perindo, PAN, PKS, PPP and $\mathrm{PKB}$

Golkar, PDIP, Gerindra, and Perindo

PDIP, Gerindra and NasDem 
15 Debby Vita Dewi

16 Winda Fitrika

17 Aji Setyawan

18 Etik Suryani

19

Kustini Sri

20 Anton Saragih
Deputy Regent of South Bangka

Deputy Regent

of Asahan

Mayor of

Magelang

Regent of

Sukoharjo

Regent of

Sleman

Regent of

Simalungin
Jamro's Wife

Taufan Gama

Simatupang's

Wife

Sigit

Widyonindito's

Son

Wardoyo

Wijaya's Wife

Sri Purnomo'

Wife

Brother JR

Saragih
PDIP, PPP and PBB

PDIP and Hanura

PDIP, Hanura, Partai Gerindra and Perindo

PDIP, Golkar and Nasdem

PDIP and PAN

PDIP, NasDem and PAN

The presence of candidates who have a kinship with political officials is massive. At the central level, the president and vice president each have families that participate in the 2020 local election contest. Several ministers also have kinship with candidates, including: Prabowo Subianto, Pramono Anung, Syahrul Yasin Limpo and Ida Fauziah. In the regions, the mobilization of family members to become candidates for regional head and deputy regional heads is even more massive.

Kompas Research and Development surveyed political dynasties. The survey results showed that $69.1 \%$ of respondents said they would vote for regional head candidates because of their abilities, regardless of whether they had family ties or not with political officials. Meanwhile, 21.9\% thought that they did not vote because they were relatives of public officials, $7.7 \%$ said they did not know, and $1.3 \%$ said they would vote because of public officials' family. However, from the survey, $58 \%$ agreed that there was a prohibition or restriction for political officials' families to participate in the regional elections. As many as $35.7 \%$ disagreed, and $6.2 \%$ did not know. Furthermore, $60.8 \%$ stated that dynastic political practice is a bad thing. Only $28.2 \%$ had a good opinion, and $11 \%$ did not know.

This phenomenon is an anomaly in a country that adheres to a democratic system. This phenomenon arises because there is a reorganization of traditional forces. The revitalization of this traditional power occurred after decentralization in 2001 and the direct local election in 2005. Local elite groups took advantage of these opportunities by optimizing political, social and family networks so that they obtained considerable public support.

At the implementation of the 2020 local election, of the 270 regions that held, 30 regions were practising political dynasties or around $11 \%$. This figure is still relatively small, but this figure may continue to increase every local election implementation period if improvements are not carried out immediately upstream to downstream. 


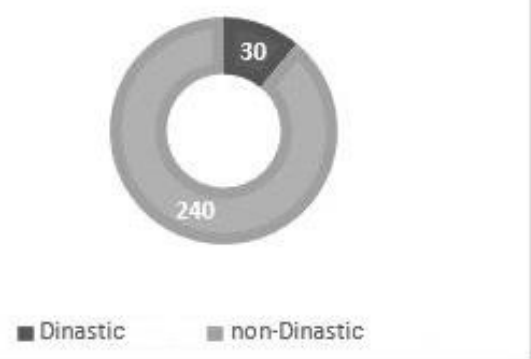

Graph 1. Dynastic vs non-Dynastic

Source: processed by researcher

There are several types of kinship status in the 2020 local election that include family members in electoral political contestation. For example, President Jokowi and Vice President Ma'ruf Amin have son registered as candidates for the regional elections as candidates for mayor of Solo and South Tangerang, and Jokowi's son-in-law is running as a candidate for mayor of Medan. Moreover, several other political officials have other kinship relationships with candidates both side-to-side (wife/husband, siblings, in-laws) and downward (son and nephews).

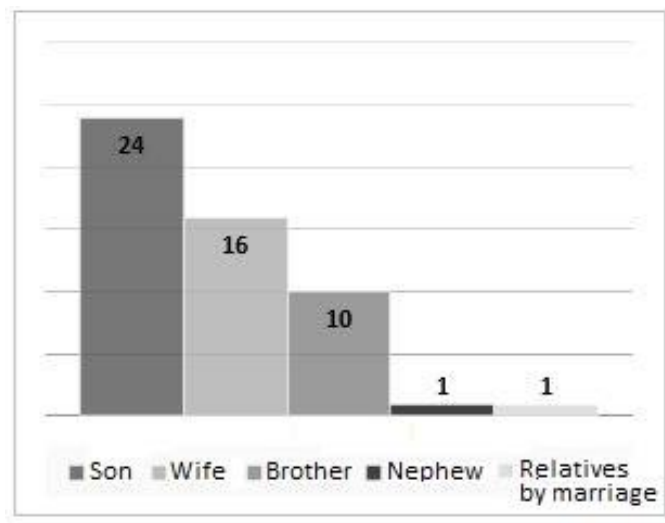

\section{Graph 2. Kinship Status}

Source: The Indonesian Intitute, 2020

Unable to resolve the political dynasty, which is a problem in the implementation of local election, the presence of a single candidate adds to the burden of the democratic process at the local level. The presence of a single candidate was present as a consequence of the simultaneous local election system. The decision of the Constitutional Court (MK) No.100 / PUUXIII / 2015 opened vast the opportunity for the local election to be held even though only one pair of regional head candidates participated consequence, an Empty Box was presented as the opponent of the match.

Table 3. Single Candidates

\begin{tabular}{cccc}
\hline Period & Area & Win & Lost \\
\hline 2015 & 3 areas & 3 areas & - \\
2017 & 9 areas & 9 areas & - \\
2018 & 16 areas & 15 areas & 1 area \\
2020 & 25 areas & 25 areas & - \\
\hline
\end{tabular}

Source: processed by researcher

After four periods of simultaneous local election implementation, a single candidate always has an increase in each implementation. The simultaneous local election, which was held for the first time in 2015, only presented three pairs of single candidates; in 2016, it increased three times to 9 pairs, in 2018 it became 16 pairs, and in 2020 was the highest number of previous local election, namely 25 pairs of single candidates. Moreover, all of them were won by 
a single candidate. This number may increase every time the local election is held simultaneously. The reason is that almost all of the 3 local election were won by a single candidate, except for the 2018 Makassar. The chances of winning are more promising by advancing as a single candidate by buying political parties, so that prospective candidates have little chance of participating in local election contestation.

Table 4. Single Candidates for the 2020 Local Elections

\begin{tabular}{|c|c|c|c|}
\hline No & Candidates & Status & Area \\
\hline 1 & $\begin{array}{l}\text { Dosmar Banjarnahor - Oloan } \\
\text { P. Nababan }\end{array}$ & Incumbent-non Incumbent & Humbang Hasundutan \\
\hline 2 & $\begin{array}{l}\text { Lakhomizaro Zebua - Sowa'a } \\
\text { Laoli }\end{array}$ & Incumbent-Incumbent & Gunungsitoli \\
\hline 3 & $\begin{array}{l}\text { Asner Silalahi } \quad-\text { Susanti } \\
\text { Dewayani }\end{array}$ & $\begin{array}{l}\text { non Incumbent-non } \\
\text { Incumbent }\end{array}$ & Pematangsiantar \\
\hline 4 & Benny Utama - Sabar AS & $\begin{array}{l}\text { non Incumbent-non } \\
\text { Incumbent }\end{array}$ & Pasaman \\
\hline 5 & Kuryana Azis - Johan Anuar & Incumbent-Incumbent & Ogan Komering Ulu \\
\hline 6 & $\begin{array}{l}\text { Popo Ali Martopo - Sholehien } \\
\text { Abuasir }\end{array}$ & Incumbent-Incumbent & South Ogan Komering Ulu \\
\hline 7 & Mian - Arie Septia Adinata & Incumbent-Incumbent & North Bengkulu \\
\hline 8 & $\begin{array}{l}\text { Mohammad Said Hidayat - } \\
\text { Wahyu Irawan }\end{array}$ & Incumbent-non Incumbent & Boyolali \\
\hline 9 & $\begin{array}{l}\text { Sri Sumarni - Bambang } \\
\text { Pujiyanto }\end{array}$ & Incumbent-non Incumbent & Grobogan \\
\hline 10 & $\begin{array}{l}\text { Arif Sugiyanto - Ristawati } \\
\text { Purwaningsih }\end{array}$ & Incumbent-non Incumbent & Kebumen \\
\hline 11 & Hendrar PH - Hevearita GR & Incumbent-Incumbent & Semarang \\
\hline 12 & 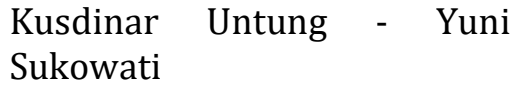 & Incumbent-non Incumbent & Sragen \\
\hline 13 & $\begin{array}{l}\text { Afif Nurhidayat - Muhammad } \\
\text { Albar }\end{array}$ & $\begin{array}{l}\text { non Incumbent-non } \\
\text { Incumbent }\end{array}$ & Wonosobo \\
\hline 14 & Hanindhito HP - Dewi MUP & $\begin{array}{l}\text { non Incumbent-non } \\
\text { Incumbent }\end{array}$ & Kediri \\
\hline 15 & Ony Anwar Harsono - Dwi RJ & Incumbent-non Incumbent & Ngawi \\
\hline 16 & $\begin{array}{l}\text { I Nyoman Giri Prasta - I Ketut } \\
\text { Suiasa }\end{array}$ & Incumbent-Incumbent & Badung \\
\hline 17 & W Musyafirin - Fud Syaifuddin & Incumbent-Incumbent & West Sumbawa \\
\hline 18 & Rahmad Mas'ud - Thohari Aziz & Incumbent-non Incumbent & Balikpapan \\
\hline 19 & Edi Damansyah - Rendi Solihin & Incumbent-non Incumbent & Kutai Kartanegara \\
\hline 20 & $\begin{array}{l}\text { Adnan P I - Abdul Rauf } \\
\text { Malaganni }\end{array}$ & Incumbent-Incumbent & Gowa \\
\hline 21 & $\begin{array}{l}\text { H. A. Kaswadi Razak - Luthfi } \\
\text { Halide }\end{array}$ & Incumbent-non Incumbent & Soppeng \\
\hline 22 & $\begin{array}{l}\text { H. M. Aras T - H Muha Amin } \\
\text { Jasa }\end{array}$ & Incumbent-Incumbent & Cental Mamuju \\
\hline 23 & $\begin{array}{l}\text { Markus Waran - Wempie } \\
\text { Welly Rengkung }\end{array}$ & Incumbent-Incumbent & South Manokwari \\
\hline 24 & $\begin{array}{l}\text { Yosias Saroy - Marinus } \\
\text { Mandacan }\end{array}$ & Incumbent-Incumbent & Pegunungan Arfak \\
\hline 25 & $\begin{array}{l}\text { Abdul Faris Umlati - Orideko I } \\
\text { Burdam }\end{array}$ & Incumbent-non Incumbent & Raja Ampat \\
\hline
\end{tabular}

Source: processed by researcher

The data above shows that of the 25 single candidates, only 4 are not incumbents. This means that the incumbent has a greater chance of advancing as the sole candidate. The incumbent has more considerable capital, economic, social, and political capital, so political 
parties with a pragmatism attitude want to win early flock to nominate the incumbent. The capital owned blocks the potential presence of other candidates because they do not have access like that of the incumbent. A single non-incumbent candidate has different reasons, either because he did not receive a party recommendation like Wonosobo and Pematangsiantar. The incumbent had served for two terms, such as Pasaman and Kediri.

Squire has investigated this phenomenon in the case of America, the combination of solid economic capital with high electability in the incumbent, presents a scare-off effect, which is a condition in which non-incumbent candidates behave not to participate in political contestation because they assume that they will experience defeat. A similar case was found in the Philippines by Sidel (2005) that other factors encourage the presence of a single candidate, namely the domination of local clans and the emergence of local bossism, which can make the candidate unchallenged, provide benefits, the domination of not access to local political sources and financial strength.

The phenomenon of a single candidate presenting the single candidate as a match has damaged the substance of political contestation, which has eliminated healthy competition between candidates. The increase in a single candidate in each local election implementation is an anomaly because Indonesia adheres to a multi-party system. Supposedly, every party or coalition of political parties should bring their best cadres to advance in every election for political officials. According to Anggraini, so far, there are two types of single candidates: a single candidate for the incumbent and a single candidate for the family of the person in power (Jay, 2018).

The problem is that the single candidate who generally is the incumbent does not always have a good performance. This phenomenon has given rise to suspicions of an evil agreement between a political party and a single candidate. The Director of Perludem stated that if the incumbent's performance was not good, the performance was not supportive, and the candidates who emerged were still single. There would be allegations of pragmatism and politics (Jay, 2018). A single candidate is legal based on the regulations on local election. However, this damages the substance of democracy. Political competition for the best leaders has stalled. Even a single candidate who is elected will be difficult to monitor because they support the majority of seat holders in the legislature.

Candidate pairs participating in local elections are dominated by proposals from political parties or coalitions of political parties. Meanwhile, political parties' failure to carry out regeneration and the pragmatism of political parties in elections only seek victory for power. Potential cadres cannot compete with the power of figures who choose qualified electability (Rosanti, 2020). It is still a debate to date, is the presence of a single candidate because of the candidate who bought up all the parties in the legislature or the party that jointly nominated the same candidate?

Political contestation must be competitive, but the presence of a single candidate almost nullifies the competition. Whereas elections with a contestation mechanism are crucial because they are based on three considerations, namely: (1) institutional arrangements to reach a political consensus where power is obtained through competitive struggles to get voter votes, (2) presenting responsive democracy, namely elected political officials, the election which is free and fair, inclusive voting rights, and the right to compete in order to win political office, and (3) provide support or legitimacy for decision-makers, namely the government elected through competitive contestation.

\section{Recruitment and Candidate Selection}

Political recruitment can be defined as the way prospective candidates are interested in competing for political office. In contrast, candidate selection is a process in which candidates are selected from among a pool of potential candidates (Siavelis \& Morgenstern, 2008). Political recruitment can be defined as how prospective candidates are interested in competing for political office. In contrast, candidate selection is a process in which candidates are selected from among a pool of potential candidates (Siavelis \& Morgenstern, 2008). These two processes are a form of selecting political parties to produce candidate leaders elected by the people. The 
role of political parties in a democratic system has a significant impact on the country going forward.

In most established democracies, there are no laws governing parties to elect their candidates, and each party is free to make its own rules. Some that have such laws include the United States, Germany, New Zealand, Norway (until 2002), and Finland. In the United States, each state determines in detail how parties elect their candidates (Rahat, 2007).

Studies on political recruitment and candidate selection are mostly done by researchers, Rahat (2007). Rahat argues that generally, there are two systems used by political parties, namely inclusive and centralized/decentralized. The first is who the voters are (in other words, how inclusive is the "selectorate" that selects candidates from the party?). The second is where the elections occur (in other words, is it centrally controlled or not?). In the territorial sense, the second parameter relates to whether a candidate is elected at the national or regional level.

Starting from Rahat's opinion, Indonesia's party system is still very exclusive because the candidate selection process is determined by a handful of party elites whose candidate candidates are determined at the center. Party leaders play a central role in candidate selection. Therefore, Norris has an analysis of the degree of centralization in the candidate process. In some of the countries that Norris has studied, parties do not want the delegation of authority to elect candidates to the regions because voters may not have a solid partisan identification, thereby significantly reducing the importance of party prerogatives (Siavelis \& Morgenstern, 2008).

Inclusiveness involves the number of people involved in selecting a candidate, with important implications for candidate loyalty. While inclusiveness and centralization may overlap, candidates' choice can be decentralized but exclusive, with local figures selecting candidates; or it can be decentralized and inclusive if elections are initiated openly to be used to elect candidates (Siavelis \& Morgenstern, 2008).

However, it cannot be denied that elitism in decision-making in political parties has become a massive general phenomenon; this is what Michels in Purwaningsih \& Subekti (2017) calls a political oligarchy, that is, a handful of elites only controls organizations. This oligarchic process is proof that the party system is ineffective. This cannot be separated from the causal relationship between political parties and pragmatic people. Political parties are periodically present in the community ahead of elections to get legitimate power legitimacy so that the people are only used as vehicles to gain power. Likewise, the relationship between candidates and political parties formed on an ad hoc basis, is only personal, not political, and only occurs before the election. After that, the candidate is the focus of the campaign. The material barely refers to the party platform. Together with the funds raised from candidates and relatives, the personal and family networks of the candidates are crucial in determining the electoral contestation (Buehler \& Tan, 2018).

The process of recruitment and candidate selection at internal political parties that do not work well is why the democratic process in Indonesia is running in place upstream. The presence of a single political dynasty and a single candidate was also caused by the two processes' destructive results. As described above, the political dynasty candidate and the single candidate have a greater chance of winning than other candidates. This potential is used by parties and candidates to want to win the contest earlier. This gap provides an entry point for potential corruption to occur by buying up political parties. As the KPK finds that in the 2018 local election, a number of candidates paid dowries to political parties ranging from 50-500 million per seat. 
Table 5. The 2020 Local Election Political Dynasty Candidate Bearer Party

\begin{tabular}{clc}
\hline No & \multicolumn{1}{c}{ Party } & Total Area \\
\hline 1 & PDI-Perjuangan & 28 \\
2 & Golkar & 23 \\
3 & PAN & 23 \\
4 & Nasdem & 14 \\
5 & Demokrat & 14 \\
6 & PKB & 11 \\
7 & PBB & 10 \\
8 & Gerindra & 8 \\
9 & PPP & 8 \\
10 & Hanura & 8 \\
11 & PSI & 2 \\
12 & Berkarya & 2 \\
13 & Perindo & 2 \\
\hline
\end{tabular}

PDI-Perjuangan, as the winning party for the 2019 Election, is the party that carries the most candidates affiliated with political officials. For example, the candidates for mayor of Solo and Medan are Joko Widodo's son and son-in-law, who displaced many potential cadres who first served the party. This, of course, cannot be separated from the authority of President Joko Widodo. The goal is to win electoral political contestation more easily and maintain a political balance between the centre and the regions.

Table 6. The 2020 Local Election Single Candidate Candidate Bearer Party

\begin{tabular}{clc}
\hline No & \multicolumn{1}{c}{ Party } & Total Area \\
\hline 1 & PDI-Perjuangan & 24 \\
2 & Golkar & 24 \\
3 & PAN & 17 \\
4 & Nasdem & 20 \\
5 & Demokrat & 18 \\
6 & PKB & 17 \\
7 & PBB & 2 \\
8 & Gerindra & 17 \\
9 & PPP & 14 \\
10 & Hanura & 13 \\
11 & PSI & 1 \\
12 & Perindo & 8 \\
13 & PKPI & 7 \\
\hline
\end{tabular}

According to (Norris \& Lovenduski, 2017) the political recruitment mechanism in the case of single candidates and political dynasties is a form of compartmentalization type recruitment, namely a form of political recruitment based on pragmatic considerations, a mixture of meritocracy and partiality. Candidate selection in determining candidates is ostensibly meritocratic, but it is centralistic in the final determination by the party. Party elites prioritize capital ownership, electability, and several other indicators that can win the contest.

This process of decay of democracy will continue if there are no internal improvements to political parties. If political parties carry out their functions properly, namely selecting candidates inclusively based on the merit system, they will have many references to determine their leaders. However, if this phenomenon is neglected, political dynasties and single candidates may be more fertile. These two phenomena are what destroy Indonesia's democratic order in the future.

\section{CONCLUSSION}

The phenomenon of political dynasties and single candidates comes because of political parties' pragmatic attitude who want to win electoral political contestation early. Political parties pay more attention to candidates from dynasties who have a kinship with political 
officials and single candidates because they have a greater chance of winning the contestation. Political parties' political recruitment and candidate selection are the entry points for the fertility of these two phenomena in the local realm. Both political dynasties and single candidates in each local election implementation period have always experienced an increase. The numbers of candidates for political dynasties and single candidates may increase in the next local election.

\section{REFERENCE}

Buehler, M. (2007). Rise of the clans: Direct elections in South Sulawesi show that a new breed of political godfathers is coming to power in Indonesia's regions. Inside Indonesia 90.

Buehler, M., \& Tan, P. (2018). Party-Candidate Relationships in Indonesian Local Politics: Regional Elections in Gowa, A Case Study of the 2005 South Sulawesi Province. Indonesia, 12(2), 5-23.

Feinstein, B. D. (2010). The dynasty advantage: Family ties in congressional elections. Legislative Studies $\quad$ Quarterly, 35(4), 571-598. https://doi.org/10.3162/036298010793322366

Fiva, J. H., \& Smith, D. M. (2013). Political Dynasties and the Incumbency Advantage in Party-Centered Environments. CESifo Working Papers, 1-19. https://www.google.com/\%5Cnpapers2://publication/uuid/D6B00033-2B564E1C-8AB5-7BFC69F3D78B

Geys, B. (2017). Political Dynasties, Electoral Institutions and Politicians' Human Capital. Economic Journal, 127(605), F474-F494. https://doi.org/10.1111/ecoj.12444

Hadiz, V. R. (2004). Decentralization and democracy in Indonesia: A critique of neoinstitutionalist perspectives. Development and Change, 35(4), 697-718. https://doi.org/10.1111/j.0012-155X.2004.00376.x

Hamid, A. (2015). Observation of Democratic Decentralization in Indonesia during 20092014: Political Dynasty in Banten Province and Populism in Jakarta Province A. Doshisha University, Kyoto, Japan.

Jay, A. (2018, September 25). Single Candidate Pilkada: Party Failure and Budget Waste. Https://Tirto.Id.

Mendoza, R. U., Beja, E. L., Venida, V. S., \& Yap, D. B. (2012). Inequality in democracy: Insights from an empirical analysis of political dynasties in the 15th Philippine Congress. https://doi.org/10.1080/01154451.2012.734094

Norris, P., \& Lovenduski, J. (2017). If Only More Candidates Came Forward': Supply-Side Explanations of Candidate Selection in Britain. British Journal of Political Science, 23(3), 373-408. https://doi.org/10.1017/S0007123400006657

Nurmandi, A., Purnomo, E. P., \& Prianto, A. L. (2015). The current practice of citizen participation in Indonesia netizen and selected cases of local democracy in Indonesia. In Citizen Participation.

Perludem. (2020). Pilkada, Between Dynasty and Empty Box.

Purwaningsih, T. (2015). Politik Kekerabatan dan Kualitas Kandidat di Sulawesi Selatan. Jurnal Politik, 1(1), 97-123. https://doi.org/10.7454/jp.v1i1.10

Purwaningsih, T., \& Singka Subekti, V. (2017). Political Family and Intra-Party Democracy in Indonesia. (A Study on the Political Recruitment of the Golkar Party during the Reform Era in South Sulawesi). Journal of Government and Politics, 8(1). https://doi.org/10.18196/jgp.8154

Querubin, P. (2013). Dynasties in the Philippines *. In APSA 2012 Annual Meeting Paper.

Rahat, G. (2007). Candidate selection: The choice before the choice. Journal of Democracy, 18(1), 157-170. https://doi.org/10.1353/jod.2007.0014

Rosanti, R. (2020). Political Pragmatics in Indonesia: Candidates, the Coalition of Political Parties and Single Candidate for Local Elections. Jurnal Bina Praja, 12(2), 153-165.

Rusnaedy, Z. (2020). Dinasti Politik di Aras Lokal. Penerbit Deepublish. 
Rusnaedy, Z., \& Purwaningsih, T. (2018). Keluarga Politik Yasin Limpo Pada Pemilihan Kepala Daerah di Kabupaten Gowa Tahun 2015. Jurnal Politik, 3(2), 301-322. https://doi.org/10.7454/jp.v3i2.116

Siavelis, P. M., \& Morgenstern, S. (2008). Candidate recruitment and selection in Latin America: A framework for analysis. Latin American Politics and Society, 50(4), 27- 58. https://doi.org/10.1111/j.1548-2456.2008.00029.x

Sidel, J. T. (2005). Bossism and democracy in the Philippines, Thailand and Indonesia: towards an alternative framework for the study of 'local strongmen.' In J. Harriss (Ed.), Politicising democracy. Demos.

Smith, D. M. (2012). Succeeding in Politics: Dynasties in Democracies. (Doctoral Dissertation, UC San Diego).

The Indonesian Intitute. (2020). The Indonesian Forum Series 65 "Dynastic Politics and the Challenge of Democracy." 